UDC 323

Submitted: 29.01 .2020

LBC 66.3(5Кит)

Accepted: 16.03 .2020

\title{
UNIVERSITIES OF CHINA: CURRENT STATUS AND GLOBAL DEVELOPMENT STRATEGY UNTIL 2035
}

\author{
Tatiana L. Guruleva \\ Institute of Far Eastern Studies of the Russian Academy of Sciences, Moscow, Russian Federation; \\ Russian State Social University, Moscow, Russian Federation
}

\begin{abstract}
Introduction. Now China is completing the "State program for medium and long-term reform and development of education for 2010-2020." The results achieved during the implementation of this program and the new strategy for the development of China's education, including in the field of higher education and higher education institutions, are becoming a new subject of research in domestic science and require careful study. The purpose of the study is to characterize the current state of Chinese universities and identify a strategy for their development until 2035. Methods and materials. As research methods, analysis of open data sources and comparative analysis were used. The source base includes regulatory documents of the People's Republic of China in the field of education (laws, the state program and state projects), CPC documents related to the development of the education system (reports of the party congress and plenum), information resources of the Ministry of Education of the People's Republic of China (National Statistical Reports on Education Development for 2016-2018), data from QS World University Rankings and Times Higher Education World University Rankings for the period 2016-2020. Analysis. As a result of the reform, the gross enrollment ratio of high school education (10-12 grades) increased from 79.2\% (2009) to 88.8\% (2018), and higher education from $24.2 \%$ (2009) to $48.1 \%$ (2018). The fulfillment of the tasks of reforming the higher education system, including the implementation of Projects 211 and 985, by the beginning of the $13^{\text {th }}$ five-year plan (2016) has enabled 85 Chinese universities to enter the world ranking THE (2016-2017). In 2016, China switched to a new strategy for the global development of higher education, embarking on the implementation of the "Project of First-Class Universities and Scientific Disciplines". At the $19^{\text {th }}$ CPC Congress (2017), this strategy was supplemented by the task of intensive development of higher education. Currently, the global development strategy for higher education and universities in the country is continuing as part of the overall modernization of education, according to which China plans to strengthen the combined power and influence of country's education in the international arena by 2020, and by 2035 to increase the competitiveness of higher education in the context of transforming the country into a global educational power. Results. The results of the study include the following: 1) the current state of Chinese universities significantly exceeds the state of 2009 in both quantitative and qualitative indicators; 2) the modern strategy for the development of higher education is the strategy of global development of Chinese universities, aimed at their achievement of leading and first positions in the world, as well as strengthening the competitiveness of China's higher education, contributing to the transformation of China into a world educational power in 2035.

Key words: education system of the PRC, reform of education of the PRC, modernization of education of the $\mathrm{PRC}$, universities of the PRC, higher education in China.
\end{abstract}

Citation. Guruleva T.L. Universities of China: Current Status and Global Development Strategy Until 2035. Vestnik Volgogradskogo gosudarstvennogo universiteta. Seriya 4. Istoriya. Regionovedenie. Mezhdunarodnye otnosheniya [Science Journal of Volgograd State University. History. Area Studies. International Relations], 2020, vol. 25, no. 2, pp. 185-197. (in Russian). DOI: https://doi.org/10.15688/jvolsu4.2020.2.13

\section{УНИВЕРСИТЕТЫ КНР: СОВРЕМЕННОЕ СОСТОЯНИЕ И СТРАТЕГИЯ ГЛОБАЛЬНОГО РАЗВИТИЯ ДО 2035 ГОДА}

\author{
Татьяна Леонидовна Гурулева
}

Институт Дальнего Востока РАН, г. Москва, Российская Федерация; Российский государственный социальный университет, г. Москва, Российская Федерация 
Аннотация. В статье рассмотрены вопросы функционирования и перспективной стратегии развития китайских университетов до 2035 года. В качестве методов исследования были использованы анализ открытых источников данных и сопоставительный анализ. Источниковой базой явились нормативно-правовые документы КНР в области образования (законы, государственная программа и государственные проекты), документы КПК, касающиеся развития системы образования (доклады съезда партии и пленума), данные информационных ресурсов Министерства образования КНР (Национальные статистические отчеты по развитию образования за 2016-2018 гг.), данные мировых рейтингов университетов QS World University Rankings и Times Higher Education World University Rankings за период 2016-2020 годов. Исследование показало, что выполнение «Государственной программы среднесрочной и долгосрочной реформы и развития образования на 2010-2020 гг.» создало благоприятные условия для развития высшего образования Китая. В результате реформы валовый коэффициент охвата образованием средней школы старшей ступени (10-12 кл.) возрос с 79,2 \% (2009 г.) до 88,8 \% (2018 г.), а высшим образованием - с 24,2 \% (2009 г.) до 48,1% (2018 г.). Выполнение задач реформирования системы высшего образования, в том числе реализация Проектов «211» и «985», уже к началу 13-й пятилетки (2016 г.) позволило 85 вузам Китая войти в мировой рейтинг ТНЕ (2016-2017). В 2016 г. Китай перешел к новой стратегии глобального развития высшего образования, приступив к реализации «Проекта первоклассных университетов и научных дисциплин». На 19-м съезде КПК (2017 г.) эта стратегия дополнилась задачей интенсивного развития высшего образования. В настоящее время стратегия глобального развития высшего образования и университетов страны продолжается в рамках общей модернизации образования, согласно которой Китай к 2020 г. планирует усиление совокупной мощи и влияния образования страны на международной арене, а к 2035 г. - повышение конкурентоспособности высшего образования в контексте превращения страны в мировую образовательную державу.

Ключевые слова: система образования КНР, реформа образования КНР, модернизация образования КНР, университеты КНР, высшее образование в Китае.

Цитирование. Гурулева Т. Л. Университеты КНР: современное состояние и стратегия глобального развития до 2035 года // Вестник Волгоградского государственного университета. Серия 4, История. Регионоведение. Международные отношения. - 2020. - Т. 25, № 2. - С. 185-197. - DOI: https://doi.org/10.15688/ jvolsu4.2020.2.13

Введение. С начала реализации политики реформ и открытости 1978 г. Китай добился внушительных успехов в деле развития образования в стране. Реализация целого ряда государственных планов и проектов в период конца XX - начала XXI в. позволила Китаю выйти на ведущие позиции в области образования в мире. Одним из показателей развития образования и науки в стране являются ее университеты. В отношении вузов в Китае проводится специальная политика, направленная на повышение престижа китайских университетов во всем мире, которая на сегодняшний день имеет очевидные успехи. Поэтому изучение современного состояния китайских университетов и стратегии их развития представляется нам актуальным и востребованным.

До 2020 г. в Китае действовала «Государственная программа среднесрочной и долгосрочной реформы и развития образования на 2010-2020 гг.». В результате ее выполнения Китай достиг всех запланированных показателей в данной области и к настоящему времени осуществляет переход к новому этапу разви- тия образования в стране, который продлится до 2035 года. Достигнутые в процессе реализации программы результаты и новая стратегия развития образования Китая, в том числе и в области высшего образования и высших учебных заведений, становятся новым предметом исследований в отечественной науке и требуют тщательного изучения.

Цель исследования: охарактеризовать современное состояние китайских университетов и выявить стратегию их развития на период до 2035 года. Задачи исследования: определить структуру и условия реализации общего базового образования и высшего образования Китая; охарактеризовать государственную политику развития китайских университетов с конца XX в. по настоящее время и показать результаты ее реализации; выявить стратегию развития китайских университетов на период до 2035 года.

Методы и материалы. Для понимания структуры и условий реализации общего базового образования и высшего образования Китая был проведен анализ нормативно-правовых документов КНР в области образова- 
ния: Закона КНР об образовании и Закона КНР об обязательном образовании [22; 23], а также данных информационных ресурсов Министерства образования КНР: Национальных статистических отчетов по развитию образования за 2016-2018 годы. Исследование государственной политики в области образования и задач в сфере развития высшего образования и университетов до 2020 г. проводилось на основе анализа ряда документов: «Государственной программы среднесрочной и долгосрочной реформы и развития образования на 2010-2020 гг.» [26], Доклада генерального секретаря ЦК КПК Си Цзиньпина на 5-м пленуме ЦК КПК 18 созыва от 29 октября 2015 г., в котором были сформулированы общие цели развития образования на 13-ю пятилетку (20162020 гг.) [25], «Программы 13-го пятилетнего плана социально-экономического развития», в которой изложены основные задачи развития образования КНР на период $2016-$ 2020 гг. [27], а также «Комплексного проекта создания университетов мирового уровня и первоклассных дисциплин» [29]. Методом сопоставительного анализа были выявлены отличия Проектов 211 и 985 от нового «Проекта первоклассных университетов и дисциплин». Результаты реализации государственной политики в области развития китайских университетов в динамике оценивались на основе сопоставительного анализа данных глобальных рейтингов QS World University Rankings и Times Higher Education за периоды 2016-2017 гг. и 2019-2020 годов. Стратегия перспективного развития китайских университетов исследовалась на основе анализа Доклада генерального секретаря ЦК КПК Си Цзиньпина на 19-м Всекитайском съезде КПК [24], а также документа «Модернизация образования Китая 2035» [21].

Историография современного развития китайских университетов в отечественной науке касается различных областей их функционирования.

Наибольший интерес исследователей вызывает область международного образовательного сотрудничества китайских университетов. В данной сфере преимущественно исследуется создание совместных китайскороссийских университетов и сетевых университетов с участием России и Китая [7; 16]; реализация Китаем и Россией совместных образовательных программ в области высшего образования $[2 ; 4 ; 10 ; 11 ; 14]$; технологии адаптации и обучения российских и китайских студентов в международном образовательном пространстве университета $[6 ; 15]$.

Кроме того, предметом научных исследований является вопрос реализации мягкой силы китайскими университетами $[1 ; 13]$.

Общие вопросы структуры, функционирования, реформы и стратегии развития высшего образования Китая и китайских вузов также вызывают интерес научного сообщества и рассматриваются в трудах российских и китайских исследователей $[3 ; 5 ; 8 ; 9 ; 12]$.

Анализ. Структура системы образования КНР включает общее базовое образование и высшее образование. В Законе об образовании КНР (ст. 17) закреплены следующие виды образования: дошкольное, начальное, среднее и высшее, а также профессиональное образование и образование для взрослых (ст. 19) [23].

Дошкольное, начальное и среднее образование входят в общее базовое образование. Дошкольное образование может быть 1-летним, 2 или 3-летним, оно обеспечивается детскими садами и дошкольными группами и является платным. В 2009 г. только 50,9 \% детей в возрасте трех лет могли получать 3-летнее дошкольное образование в силу недостаточного количества дошкольных образовательных учреждений, а 1-летнее образование - всего $74 \%$ всех детей пяти лет [26]. К 2020 г. было запланировано увеличение валового коэффициента охвата 1-летним образованием до $95 \%$, 2-летним - до $80 \%$, а 3 -летним - до $70 \%$ [26]. Однако уже в 2018 г. показатель валового коэффициента охвата 3-летним образованием достиг 81,7 \%. В настоящее время Китай стремится к тому, чтобы $100 \%$ детей имели доступ к одной из трех моделей дошкольного образования. Оплата государственного дошкольного образования составляет от 125 до 800 юаней в месяц в зависимости от уровня детского сада: третий уровень - самый низкий, затем идут второй, первый и показательный уровни. В поселках и волостях стоимость посещения государственных детских садов ниже, чем в городах. 
Следующим видом образования является общее начальное образование. Учебными заведениями, предоставляющими возможности данного вида образования, выступают начальные общеобразовательные школы и специальные пункты обучения, созданные в малочисленных населенных пунктах труднодоступных горных территорий Китая. В начальной школе принята шестилетняя система обучения с 6 до 12 лет (1-6 классы). С начала XXI в. в некоторых районах Китая осуществляется экспериментальное обучение по пятилетней системе. Для средней общеобразовательной школы характерна двухступенчатая структура, обе ступени которой длятся по три года (7-9 классы и 10-12 классы соответственно). Первая ступень средней школы наряду с начальной школой входят в систему обязательного девятилетнего образования (1-9 классы), гарантированного законами КНР [22; 23]. Обязательное девятилетнее образование является бесплатным. Обучение в государственной средней общеобразовательной школе старшей ступени (10-12 классы) платное, оно колеблется от 200 юаней (в поселках и волостях) до 1500 юаней за семестр (школы городского значения в крупных городаx), также платным является проживание в общежитии (от 180 до 360 юаней в месяц в зависимости от категории общежития, которая бывает третьей, второй и первой).

Кроме общего образования, граждане КНР могут получить и профессиональное образование, которое разделяется на три уровня: начальный, средний и высший. Начальное и среднее профессиональное образование на 90 \% является бесплатным (в более чем 20 провинциях полностью осуществляется бесплатное среднее профессиональное образование). В государственных платных средних профессиональных учебных заведениях стоимость обучения колеблется от 1100 юаней до 4000 юаней за семестр в зависимости от вида учебного заведения (обычные и государственного значения), его местонахождения (в городах обучение дороже) и от специальности (обучение на технических и художественных специальностях дороже).

Согласно данным Национального статистического отчета по развитию образования в 2018 г. валовой коэффициент охвата 3-летним дошкольным образованием составлял 81,7 \%; коэффициент прочности обязательного девятилетнего образования - 94,2 \% (для обязательного девятилетнего образования подсчитывается не валовой коэффициент охвата, а коэффициент прочности, который представляет собой соотношение количества учащихся, поступивших в школу, и количества выпускников 9-го класса); валовой коэффициент охвата старшей ступенью средней школы, включая обучающихся старшей ступени средней профессиональной школы, $-88,8 \%$ [19].

В 2018 г. количество детских садов составляло 266 700; учреждений обязательного девятилетнего образования - 213800 (начальных общеобразовательных школ - 161800 , пунктов обучения начального образования 101 400, средних общеобразовательных школ первой ступени - 52 000); учреждений вспомогательной (коррекционной) школы - 2 152; средних школ старшей ступени - 24300 (средних общеобразовательных школ старшей ступени - 13 700, средних общеобразовательных школ старшей ступени для взрослых - 354, учреждений среднего профессионального образования - 10 200) [19].

Получение высшего образования возможно либо на базе средней общеобразовательной школы старшей ступени, либо средних профессиональных учебных заведений. Высшее образование представлено профессиональным высшим образованием и общим высшим образованием. В учреждениях профессионального высшего образования осуществляется обучение какой-либо специальности (специальное образование) - ведется подготовка по специальностям чжуанькэ, срок обучения составляет 2-3 года. В учреждениях общего высшего образования - по программам подготовки бакалавриата, срок обучения 4-5 лет. Два вида высшего образования: профессиональное и общее имеют разные специальности и направления подготовки. Так, для специальностей чжуанькэ существует перечень, включающий более 800 специальностей по 19 укрупненным группам. Для бакалавриата перечень направлений подготовки включает 13 отраслей науки, которые также распространяются на магистратуру и докторантуру. По завершении специального образования специалистам чжуанькэ не присва- 
ивается ученая степень, а выдается только диплом о высшем образовании. Тем, кто успешно освоил программу бакалавриата и защитил бакалаврскую диссертацию, выдается диплом об окончании обучения по программе бакалавра и присваивается ученая степень бакалавра. Степень бакалавра дает возможность получить постдипломное образование: освоить программу магистратуры (период обучения 2-3 года) и докторантуры (период обучения 3-4 года). Перечень ученых степеней бакалавра, магистра и доктора включает 10 отраслей науки: философия, экономика, юриспруденция, педагогика, гуманитарные науки, история, естественные науки, технические науки, сельскохозяйственные науки, медицина. Стоимость обучения по программам подготовки чжуанькэ в государственных образовательных учреждениях составляет 6 000-7 000 юаней (технические специальности от 7500 юаней и выше) за учебный год. Стоимость обучения по программам бакалавриата в государственных вузах составляет 5 000-6 500 юаней за учебный год (художественные специальности - до 10000 юаней). Стоимость обучения по программам магистратуры в государственном образовательном учреждении составляет около 8000 юаней за учебный год, а докторантуры - 10000 юаней за учебный год. Кроме того, в высшем и послевузовском государственном образовании расходы на учебную литературу составляют примерно 500-800 юаней в год, проживание в общежитии - примерно 1 000-1 200 юаней в год. Стоимость обучения во всех видах частных образовательных учреждений в 2, 3 и 4 раза выше, чем в государственных.

Согласно Перечню высших учебных заведений Китая, ежегодно публикуемому Министерством образования КНР, в 2019 г. общее количество вузов в стране составило 2 688, кроме них также было 268 вузов, осуществлявших образование взрослых [20]. Учреждений послевузовского образования, ежегодно реализующих подготовку по программам магистратуры и докторантуры, около 815 (из них общеобразовательных учреждений около 578, научноисследовательских - около 237).

Стратегическая цель реформы и развития образования, изложенная в «Государственной программе среднесрочной и долгосроч- ной реформы и развития образования на 20102020 гг.», заключается в том, чтобы к 2020 г. «в основном осуществить модернизацию образования, в основном построить общество знаний (сюэси шэхуэй) и вступить в ряды держав с высоким уровнем развития человеческого капитала (жэньли изиюань цянго) (курсив наш. - Т. Г.)» [26].

Согласно данной Программе в области развития высшего образования к 2020 г. запланировано поднять валовой коэффициент охвата населения высшим образованием до 40 \%. Кроме того, были поставлены задачи повышения качества высшего образования, качества подготовки кадров, уровня научных исследований, оптимизации структуры и организации системы высшего образования, выполнения Проектов 211 и 985 [26].

Вне всякого сомнения, Китай успешно справился с основными поставленными задачами. Так, запланированный к 2020 г. 40 \%-й валовый коэффициент охвата высшим образованием населения страны уже в 2016 г. составил $42,7 \%$, в 2017 г. $-45,7 \%$, а в 2018 г. - 48,1\% $[17 ; 18 ; 19]$. При этом необходимо учитывать, что до начала осуществления политики реформ и открытости 1978 г. валовый коэффициент охвата высшим образованием населения страны составлял всего 1,55 \%. По оценкам аналитиков, к концу 13-й пятилетки (2020 г.) этот показатель составит $50 \%$.

Заявленное в Программе продолжение реализации Проектов 211 и 985 также оказалось весьма успешным. Так, Проект 211 [название возникло из сочетания числительных 21 (XXI век) и 1 (одна сотня вузов)], начатый в 1995 г., заключался в выборе около 100 наиболее важных (ключевых) вузов КНР с целью превращения их в развитые университеты мирового уровня. В итоге Проект 211 включил 112 передовых вузов. Капиталовложения в данный проект составили 18 млрд юаней. В результате реализации проекта целый ряд китайских университетов смог выйти на мировой уровень развития, а группа приоритетных научных дисциплин занять передовые позиции среди ведущих научных дисциплин мира.

Реализация Проекта 985 [название возникло из даты начала реализации проекта: сочетания числительных 98 (1998 год) и 5 (май, 
по-китайски: 5-й месяц)] заключалась в превращении ряда высших учебных заведений в первоклассные мировые университеты. Bсего в результате реализации проекта в него было включено 39 вузов КНР, которые смогли выйти на передовые позиции в мире.

Выполнение Проектов 211 и 985 позволило Китаю за 20 лет их реализации достичь колоссальных успехов в развитии университетов. Так, уже в 2016 г. в рейтинг ТНЕ (20162017 гг.) вошли 85 вузов континентального Китая, Сянгана (Гонконга), Тайваня и Аомыня (Макао), а в первые 500 вузов рейтинга QS (2016-2017 гг.) - 41 университет материкового Китая, Сянгана и Тайваня.

Несмотря на очевидные успехи, в 2016 г. Китай выбирает новую стратегию развития вузов страны. В «Программе 13-го пятилетнего плана социально-экономического развития» (на 2016-2020 гг.) в области высшего образования акцентируются задачи выхода ряда высших учебных заведений на мировой уровень и создания первоклассных научных дисциплин, а также повышения инновационного потенциала высших учебных заведений [27].

24 октября 2015 г. Госсовет КНР распространил «Комплексный проект создания университетов мирового уровня и первоклассных научных дисциплин», направленный на развитие в Китае первоклассных университетов и отраслей науки [29]. С этого момента на смену Проектам 211 и 985 приходит проект под названием «иуан и лю» (дословно «два первоклассных», имеется в виду создание первоклассных университетов и первоклассных научных дисциплин в университетах).

Основная цель «Проекта первоклассных университетов и научных дисциплин» заключается «в оказании государством содействия лучшим университетам и передовым научным дисциплинам в их трансформации в первоклассные университеты и научные дисциплины; в ускорении модернизации системы управления высшим образованием и возможностей его управления; в повышении инновационного уровня подготовки кадров, научных исследований, общественных услуг и наследования культуры с тем, чтобы первоклассные университеты и научные дисциплины стали основной платформой научных открытий и научнотехнических инноваций, основным источником передовых идей и выдающейся культуры, основной базой подготовки высококвалифицированных кадров и играли важную роль в поддержании государственных инновационных стратегий развития, в служении социальноэкономическому развитию, в эволюции выдающейся традиционной китайской культуры, в воспитании и претворении в жизнь базовых социалистических ценностей, в содействии интенсивному развитию высшего образования〉 [29].

Основными задачами реализации проекта названы: к 2020 г. добиться выхода нескольких университетов и ряда научных дисциплин на ведущие мировые позиции, а нескольких научных дисциплин - на первые позиции в мире; к 2030 г. - увеличить количество университетов и научных дисциплин, вышедших на ведущие мировые позиции, добиться выхода нескольких университетов и ряда научных дисциплин на первые позиции в мире, значительно повысить суммарную мощь высшего образования; к середине века - выйти на первые позиции в мире по количеству и мощи первоклассных университетов и научных дисциплин и в основном добиться цели превращения страны в мировую образовательную державу [29].

Под одним из базовых терминов указанного проекта - «сюекэ» (то есть «научная дисциплина») - понимается относительно самостоятельная система научного знания с определенным объектом, предметом и методами исследования. В китайской науке выделяют 13 отраслей: философия, экономика, право, образование, литература, история, естественные науки, технология, сельское хозяйство, медицина, менеджмент, военная наука, искусствоведение. Далее указанные отрасли делятся на два уровня: первый и второй. В первый уровень входят 111 научных дисциплин, которые затем разделяются на дисциплины более мелкого второго уровня. Например, научная отрасль «право» делится на 6 научных дисциплин первого уровня: юриспруденция, политология, социология, этнология, марксистская теория и общественная безопасность. Далее, например, научная дисциплина первого уровня «социология» подразделяется на научные дисциплины второго уровня: историю социологии, теорию социологии, методы социоло- 
гии и другие научные дисциплины. Проект подразумевает развитие научных дисциплин и первого и второго уровней. Так, в Пекинском университете более 40 научных дисциплин признаны передовыми, на основании чего в проект вошел весь университет, а в Пекинском транспортном университете передовой по уровню развития признана только одна научная дисциплина, поэтому только эта дисциплина и участвует в проекте.

Причинами замены Проектов 211 и 985 на «Проект первоклассных университетов и научных дисциплин», на наш взгляд, являются следующие: 1) утрата за почти двадцать лет реализации Проектов 211 и 985 их «идейной новизны» в сравнении с новыми идеологическими концептами, предложенными «пятым поколением» руководителей КНР; 2) необходимость концентрации усилий по созданию университетов мирового уровня, что удобнее делать в рамках одного проекта, а не двух; 3) достижение Проектами 211 и 985 предела своего развития (то есть создания более сотни ключевых вузов, из которых наибольшего уровня развития достигли 39), который не позволял дальше выполнять задачу развития китайских университетов; 4) смена стратегии развития высшего образования и китайских университетов с «внутренней», то есть создания университетов, сопоставимых по уровню развития с ведущими университетами мира, на «внешнюю», направленную на достижение широкого присутствия китайских университетов на высоких позициях мировых рейтингов, как институциональных, так и отраслевых и предметных; 5) удобство внутригосударственного ранжирования китайских вузов, которое проще осуществлять в условиях функционирования единой системы развития вузов.

Основными отличиями нового «Проекта первоклассных университетов и научных дисциплин» от предыдущих проектов представляются следующие: 1) предметом оценки для включения в новый проект является уровень развития научных дисциплин, а не вузов в целом, как это было в Проектах 211 и 985; вузы включаются в проект на основании наличия у них передовых научных дисциплин; 2) «Проект первоклассных университетов и научных дисциплин» является «открытым» проектом, включение и исключение из которого возможно для любого вуза, в то время как старые проекты были «закрытыми»: вузы, однажды попавшие туда, уже не могли быть исключены из проекта, а новым вузам, не вошедшим в сформированную сотню, уже было довольно сложно попасть в эти проекты; 3) вузы, входящие в Проект 985, были «элитными», напрямую подчиненными Министерству образования КНР, а университеты Проекта 211 также были вузами высокого провинциального подчинения; новый проект доступен для участия любого вуза, любого подчинения; 4) два предыдущих проекта с точки зрения вузов-участников были взаимосвязаны между собой: все вузы Проекта 985 входили в число вузов Проекта 211 и были «самыми элитными из элитных»; новый Проект не использует указанную модель. Несмотря на то что в новый проект вошла большая часть вузов старых проектов, все же в него смогли попасть и новые университеты, имеющие высоко развитые научные специальности.

В докладе на 19-м съезде КПК (18-24 октября 2017 г.) Председатель КНР Си Цзиньпин отметил, что «основой великого возрождения китайской нации является превращение Китая в мировую образовательную державу (цзяоюй иянго)». В связи с этим необходимо «осуществлять приоритетное развитие образования, ускорить модернизацию образования, создать образование, удовлетворяющее потребностям народа». В области высшего образования 19-й съезд отметил необходимость ускорения создания высших учебных заведений мирового уровня и развития первоклассной науки, а также необходимость осуществления интенсивного развития высшего образования [24].

Содержание понятия «интенсивное развитие высшего образования» в настоящее время активно обсуждается и разрабатывается общественностью и исследователями Китая. Так, например, Ассоциациия высшего образования Китая полностью посвятила данной проблематике два первых номера своего научного журнала «Обзор научных исследований в области образования в Китае» за 2020 год. В обобщенном виде под интенсивным развитием высшего образования понимается: 
- повышение уровня обучения в системе высшего образования и качества итоговой подготовки выпускников;

- реформа различных макро- и микроуровневых систем и механизмов, сдерживающих повышение уровня и качества подготовки кадров в высших учебных заведениях;

- улучшение педагогических условий и образовательной среды системы высшего образования;

- непрерывная оптимизация процесса подготовки кадров в системе высшего образования;

- разработка моделей подготовки специалистов, соответствующих разным уровням и видам системы высшего образования;

- гарантия соответствия подготовки специалистов в системе разных уровней и видов высшего образования не только личному образовательному статусу обучающихся, но и их ожиданиям от системы высшего образования, а также государственным и региональным потребностям социально-экономического развития; гарантия повышения роли высшего образования в воспитании качеств национального характера, в общественном и цивилизационном прогрессе.

В феврале 2019 г. ЦК КПК и Госсовет КНР опубликовали совместный документ под названием «Модернизация образования Китая 2035», в котором к 2020 г. поставлена цель выполнить все задачи 13-й пятилетки, значимо усилить совокупную мощь образования и его влияние на международной арене, значимо повысить средние периоды обучения людей трудоспособного возраста, добиться серьезного прогресса модернизации образования, внести весомый вклад во всестороннее построение среднезажиточного общества (сяокан шэхуэй). На этой базе в ближайшие 15 лет, к 2035 г., планируется в основном осуществить модернизацию образования, войти в список мировых образовательных держав, способствовать превращению Китая в страну с высоким уровнем доступности образования (сюэси даго), в державу с высоким уровнем развития человеческого капитала (жэньли изиюань ияяго) и квалифицированных кадров (жэньцай иянго), заложить прочную основу для превращения Китая к середине этого века в демократическую, цивилизо- ванную, гармоничную и прекрасную социалистическую модернизированную державу. Основная задача развития высшего образования к 2035 г. заключается в повышении его конкурентоспособности [21].

На сегодняшний день процесс создания университетов мирового уровня и первоклассных научных дисциплин имеет следующие успехи. Согласно совместно обнародованному в 2017 г. Министерством образования, Министерством финансов и Государственным комитетом по развитию и реформам Перечню вузов и дисциплин мирового класса, к категории «первоклассный» относится 137 вузов страны, среди которых 42 вуза являются университетами мирового уровня (первоклассные университеты), а 95 - имеют первоклассные дисциплины [28].

При организации «Проекта первоклассных университетов и научных дисциплин» была соблюдена преемственность: все 39 вузов Проекта 985 вошли в перечень 42 университетов нового проекта. Из оставшихся вузов Проекта 211 (все вузы Проекта 985 входили в Проект 211) часть вошла в проект за счет своих первоклассных научных дисциплин. Кроме того, 26 новых вузов, ранее не участвовавших в проектах, также вошли в новый проект благодаря высокому уровню развития своих научных дисциплин. Университеты нового проекта разделены на две категории А и В. К категории А относится 36 вузов: 1. Пекинский университет; 2. Китайский народный университет; 3. Университет Цинхуа; 4. Пекинский университет авиации и космонавтики; 5. Пекинский политехнический университет; 6. Китайский сельскохозяйственный университет; 7. Пекинский педагогический университет; 8. Центральный университет национальностей (г. Пекин); 9. Нанькайский университет (г. Тяньцзинь); 10. Тяньцзиньский университет и др. К категории В относятся 6 вузов: Северо-восточный университет (г. Шэньян), Чжэнчжоуский университет, Хунаньский университет (г. Чанша) и др. Научно-образовательный потенциал университетов категории В меньше, чем категории А. В категорию В вошли 3 вуза, ранее не участвовавшие в Проекте 985, и 3 вуза из Проекта 985, которые имеют меньший потенциал развития научных дисциплин, чем университеты категории А [28]. 
В процессе реализации «Проекта первоклассных университетов и научных дисциплин» позиции китайских университетов в мировых рейтингах усилились. Если в первую сотню рейтинга THE (2016-2017 гг.) входили 2 вуза континентального Китая, то рейтинг THE (2019-2020 гг.) уже включает три университета континентального Китая: Университет Цинхуа (23-е место), Пекинский университет (24-е место) и Научно-технический университет Китая (= 80-е место), при этом хорошие шансы на вхождение в первую мировую сотню вузов имеют еще два китайских университета: Чжэцзянский университет (107-е место) и Фуданьский университет (109-е место).

Что касается рейтинга QS (2019-2020 гг.), то количество вузов континентального Китая, входящих в первую сотню, по сравнению с рейтингом QS (2016-2019 гг.) в нем увеличилось с 4 до 6: Университет Цинхуа (16-е место), Пекинский университет (=22-е место), Фуданьский университет (40-е место), Чжэцзянский университет (54-е место), Шанхайский университет транспорта (=60-е место), Научно-технический университет Китая (89-е место).

Несмотря на то что позиции университетов в мировых рейтингах подвержены ежегодным изменениям в силу различных причин, как реального повышения или понижения показателей вузов, так и совершенствования методик рейтингования и увеличения количества новых университетов, составляющих общую совокупность вузов-участников, Китай уверено движется в сторону усиления своего присутствия в списках элитных вузов планеты. Так, количество вузов континентального Китая, Сянгана, Аомыня и Тайваня в рейтинге QS (2017-2018 гг.) составило уже 63 университета (на долю континентального Китая пришлось 39), в рейтинге QS (2018-2019 гг. и 2019-2020 гг.) - 66 университетов (42 и 39 из континентального Китая), при этом ведущие вузы страны: Университет Цинхуа, Пекинский университет, Фуданьский университет, Чжэцзянский университет ежегодно значимо повышают свои позиции в первой сотне вузов мира.

Результаты. Значительные успехи, достигнутые Китаем в области развития высшего образования, а также повышение престижа китайских университетов в международном научном и образовательном простран- стве, являются закономерным результатом реформы образования, проводимой в Китае в $\mathrm{XX}$ в., направленной на развитие всех уровней образования. Реализация «Государственной программы среднесрочной и долгосрочной реформы и развития образования на 20102020 гг.» привела к укреплению фундамента высшего образования - общего базового образования, а особенно средней школы старшей ступени, валовый коэффициент охвата которой за неполные 10 лет (с 2009 г.) увеличился с 79,2 до 88,8 \% (2018 г.). Выполнение задач, поставленных в указанной программе, а также в «Программе 13-го пятилетнего плана социально-экономического развития», создало прочную базу для повышения валового коэффициента охвата высшим образованием населения с 24,2 \% (2009 г.) до 48,1 \% (2018 г.) и для реализации Проектов 211 и 985 по развитию китайских университетов, которые включили 112 и 39 вузов соответственно. В 2016 г. Китай успешно завершил реализацию указанных проектов и перешел к выполнению «Комплексного проекта создания университетов мирового уровня и первоклассных дисциплин», выбрав новую стратегию глобального развития высшего образования, заключающуюся в поэтапном выходе китайских университетов и научных дисциплин на ведущие и первые мировые позиции. Выбор этой стратегии был подтвержден на 19-м съезде КПК и дополнен задачей осуществления интенсивного развития высшего образования. Таким образом, в отличие от 18-го съезда КПК (2012 г.), ставившего задачи развития разных видов образования (дошкольного, обязательного девятилетнего, старшей ступени средней школы, профессионального, высшего, непрерывного и образования в течение всей жизни), 19-й съезд КПК сосредоточил свое внимание только на стратегии развития высшего образования, состоящей из двух ключевых моментов: 1) ускорении создания первоклассных университетов и дисциплин; 2) осуществлении интенсивного развития высшего образования. При этом новой задачей в области развития высшего образования по сравнению с 18-м съездом КПК стала именно задача ускорения создания первоклассных университетов и дисциплин, поскольку задача способствования интенсивному развитию высшего обра- 
зования ставилась ранее на 18-м съезде КПК. Очевидно, что, поставив новую задачу ускорения создания первоклассных университетов и дисциплин, Китай определил и способ ее достижения - выполнение второй задачи: интенсивного развития высшего образования. Стратегия глобального развития высшего образования получила свое дальнейшее закрепление и в новом документе «Модернизация образования Китая 2035»: 1) как выполнение всех задач 13-й пятилетки (включая задачу создания первоклассных университетов и дисциплин) и значимое усиление совокупной мощи образования Китая и его влияния на международной арене к 2020 г.; 2) как повышение конкурентоспособности высшего образования Китая в контексте его превращения в мировую образовательную державу к 2035 году. Выбранная Китаем стратегия глобального развития высшего образования и университетов оказалась настолько успешной, что за последние 4 года обеспечила Китаю не только сохранение позиций университетов Китая в ведущих международных рейтингах на фоне общей тенденции снижения рейтингов университетов, связанной с корректировкой методик рейтингования и вхождением новых университетов в общую совокупность вузов-участников, но и повышение этих позиций у целого ряда ведущих университетов страны.

\section{СПИСОК ЛИТЕРАТУРЫ}

1. Актамов, И. Г. «Мягкая сила Китая»: образовательные стратегии внешнеполитического влияния / И. Г. Актамов, Т. Б. Бадмацыренов // Власть. 2019. - № 3. - С. 231-236.

2. Ван, Л. Совместные образовательные программы университетов и российских вузов: состояние, тенденции и перспективы / Ли Ван, И. И. Баранова // Научно-технические ведомости СПбГПУ. Гуманитарные и общественные науки. - 2017. - Т. 8, № 1. - С. 134-141.

3. Ван, Я. Реформирование системы высшего образования в Китае в XX - начале XXI в. / Ян Ван // Общество: социология, психология, педагогика. 2018. - № 3. - C. 62-71.

4. Гурулева, Т. Л. Совместные образовательные программы России и Китая: состояние и проблемы реализации / Т. Л. Гурулева // Высшее образование в России. - 2018. - № 12. - С. 93-103. - DOI: https:// doi.org/10.31992/0869-3617-2018-27-12-93-103.
5. Гурулева, Т. Л. Стратегические рубежи развития системы образования КНР в XXI веке / Т. Л. Гурулева // Проблемы Дальнего Востока. 2019. - № 4. - C. 145-153. - DOI: 10.31857/ S013128120006104-5.

6. Гурулева, Т. Л. Технологии социокультурной интеграции иностранных студентов: опыт российско-китайского сотрудничества / Т. Л. Гурулева // Высшее образование в России. - 2016. - № 10. C. $148-153$.

7. Гурулева, Т. Л. Сотрудничество России и Китая в области создания сетевых университетов и совместных образовательных учреждений / Т. Л. Гурулева, Н. И. Бедарева // Высшее образование в России. - 2019. - № 4. - С. 108-123. - DOI: https://doi.org/ 10.31992/0869-3617-2019-28-4-108-123.

8. Донецкая, С. С. Реформирование системы высшего образования в Китае: современные итоги / С. С. Донецкая, Цяньнань Цзи // Высшее образование в России. - 2018. - Т. 27, № 12. - С. 79-92. - DOI: https://doi.org/10.31992/0869-3617-2018-27-12-79-92.

9. Краснова, А. А. Развитие системы непрерывного образования в Китае / А. А. Краснова // Вестник Российского университета дружбы народов. Серия: Информатизация образования. 2015. - № 3. - С. 96-105.

10. Краснова, Г. А. Сетевое взаимодействие вузов: сравнительный анализ подходов к реализации совместных образовательных программ в Китае и России / Г. А. Краснова // Вестник Российского университета дружбы народов. Серия: Информатизация образования. - 2016. - № 3. C. $123-130$.

11. Краснощеков, В. В. Обеспечение качества российско-китайских программ высшего образования / В. В. Краснощеков // Современные проблемы науки и образования. - 2019. - № 3. - Электрон. текстовые дан. - Режим доступа: $\mathrm{http}: / / \mathrm{www}$. scienceeducation.ru/ru/article/view?id=28853 (дата обращения: 18.01.2020). - Загл. с экрана.

12. Ли, Я. Новая динамика высшего образования в Китае / Яньхуэй Ли // Вестник Новосибирского государственного педагогического университета. -2015. - № 6 (28). - C. 151-160.

13. Сюн, Л. Высшее образование как инструмент «мягкой силы» России и Китая : автореф. дис. ... канд. полит. наук / Лэпин Сюн. - М., 2018. - 33 с.

14. Терещенко, Т. М. Опыт внедрения и реализации совместных российско-китайских образовательных программ / Т. М. Терещенко, А. В. Правдикова // Педагогическое образование в России. 2016. - № 10. - С. 38-42.

15. Филимонова, Н. Ю. Китайские студенты в вузах России / Н. Ю. Филимонова, Е. С. Романюк // Высшее образование в России. - 2014. - № 8-9. C. $76-81$. 
16. Филиппов, В. М. Роль Университета Шанхайской организации сотрудничества в сопряжении образовательных пространств Евразии / В. М. Филиппов, Юйхуа Сунь // Государственная служба. 2015. - № 6 (98). - Электрон. текстовые дан. - Режим доступа: https://pa-journal.igsu.ru/articles/r102/ 3560/ (дата обращения: 26.01.2020). - Загл. с экрана.

17.2016年全国 教育事、湦发 展统计 公报: [Национальный статистический отчет по развитию образования за 2016 г.]. Электрон. текстовые дан. - Режим доступа: http:// www.moe.gov.cn/jyb_sjzl/sjzl_fztjgb/201707/ t20170710_309042.html (дата обращения: 26.01.2020). - Загл. с экрана.

18.2017年全国教育事圤发 展统计公报:[Национальный статистический отчет по развитию образования за 2017 г.]. Электрон. текстовые дан. - Режим доступа: http:// www.moe.gov.cn/jyb_sjzl/sjzl_fztjgb/201807/ t20180719_343508.html (дата обращения: 26.01.2020). - Загл. с экрана.

19.2018 年全国教育事坏发 展统计公报: [Национальный статистический отчет по развитию образования за 2018 г.]. Электрон. текстовые дан. - Режим доступа: http:// www.moe.gov.cn/jyb_sjzl/sjzl_fztjgb/201907/ t20190724_392041.html (дата обращения: 26.01.2020). - Загл. с экрана.

20.2019 年全国高等学校名单: [Пepeчень высших учебных заведений КНР в 2019 г.]. Электрон. текстовые дан. - Режим доступа: http:// www.moe.gov.cn/jyb_xxgk/s5743/s5744/201906/ t20190617_386200.html (дата обращения: 26.01.2020). -Загл. с экрана.

21. 中共中央、国务院印发“中国 教育现代化: [ЦК КПК и Госсовет распространили документ «Модернизация образования Китая 2035»]. - Электрон. текстовые дан. - Режим доступа: http://www.gov.cn/zhengce/2019-02/23/ content 5367987.htm (дата обращения: 26.01.2020). Загл. с экрана.

22. 中华人民共和国义务教育法： [Закон КНР об обязательном образовании]. - Электрон. текстовые дан. - Режим доступа: http:// www.n p c.gov.cn/n p c/ c $30834 / 201901 /$ 21b0be5b97e54c5088bff17903853a0d.shtml (дата обращения: 26.01.2020). - Загл. с экрана.

23. 中华人民共和国教育法： [Закон КНР об образовании]. - Электрон. текстовые дан. - Режим доступа: http://www.crs.jsj.edu.cn/ index.php/default/news/index/13 (дата обращения: 26.01.2020). - Загл. с экрана.

24. 又近平 (Си Цзиньпин)。在中国共 产党第十九次全国代表大会上的
报告: [Доклад на 19-м Всекитайском съезде КПК]. Электрон. текстовые дан. - Режим доступа: http:// cpc.people.com.cn/n1/2017/1028/c64094-29613660.html (дата обращения: 26.01.2020). - Загл. с экрана.

25.十八届五中全会报告全文: [Доклад на 5-м пленуме ЦК КПК 18-го созыва (полный текст)]. - Электрон. текстовые дан. - Режим доступа: http://www.yjbys.com/news/389856.html (дата обращения: 15.07.2018). - Загл. с экрана.

26. 国家中长期教育改革和 发展规划纲 要 2010-2020 年: [Государственная программа среднесрочной и долгосрочной реформы и развития образования на 20102020 гг.]. - Электрон. текстовые дан. - Режим доступа: http://www.china.com.cn/policy/txt/2010-03/01/ content_19492625.htm (дата обращения: 15.07.2018). Загл. с экрана.

27. 国民经济和社会发展第十三个 五年规划纲要: [Программа 13-го пятилетнего плана социально-экономического развития]. Электрон. текстовые дан. - Режим доступа: http:// kjtg.hljxm.gov.cn/index! contentall.action? document.id=106254 (дата обращения: 26.01.2020). Загл. с экрана.

28. 教育部、财政部、国家发展改 革委关于公布世界一流大学和一流学 科建设高校及建设学科名单 通知: [Уведомление Министерства образования, Министерства финансов и Государственного комитета по развитию и реформам о публикации Перечня вузов и дисциплин мирового класса]. - Электрон. текстовые дан. - Режим доступа: http:/www.moe.gov.cn/ srcsite/A22/moe_843/201709/t20170921_314942.html (дата обращения: 26.01.2020). - Загл. с экрана.

\section{9 . 统筹推进世界一流大学和一} 流学科建设总体方案: [Комплексный проект создания университетов мирового уровня и первоклассных дисциплин]. - Электрон. текстовые дан. Режим доступа: http://www.moe.gov.cn/jyb_xxgk/ moe_1777/moe_1778/201511/t20151105_217823.html (дата обращения: 26.01.2020). - Загл. с экрана.

\section{REFERENCES}

1. Aktamov I.G., Badmatsyrenov T.B. «Myagkaya sila Kitaya»: obrazovatelnye strategii vneshnepoliticheskogo vliyaniya [China's Soft Power: Educational Strategies for Foreign Policy Influence]. Vlast, 2019, no. 3, pp. 231-236.

2. Van Li, Baranova I.I. Sovmestnye obrazovatelnye programmy universitetov i rossiyskikh vuzov: sostoyanie, tendentsii i perspektivy [Joint 
Educational Programs of Chinese Universities and Russian Universities: Status, Trends and Prospects]. Nauchno-tekhnicheskie vedomosti SPbGPU. Gumanitarnye $i$ obshchestvennye nauki [St. Petersburg State Polytechnical University Journal: Humanities and Social Sciences], 2017, vol. 8, no. 1, pp. 134-141.

3. Van J. Reformirovanie sistemy vysshego obrazovaniya v Kitae v XX - nachale XXI v. [Reforming the System of Higher Education in China in the XX Early XXI Centuries]. Obshchestvo: sotsiologiya, psikhologiya, pedagogika [Society: Sociology, Psychology, Pedagogics], 2018, no. 3, pp. 62-71.

4. Guruleva T.L. Sovmestnye obrazovatelnye programmy Rossii i Kitaya: sostoyanie i problemy realizatsii [Joint Educational Programs of Russia and China: Status and Problems of Implementation]. Vysshee obrazovanie $v$ Rossii [Higher Education in Russia], 2018, no. 12, pp. 93-103. DOI: https://doi.org/ 10.31992/0869-3617-2018-27-12-93-103.

5. Guruleva T.L. Strategicheskie rubezhi razvitiya sistemy obrazovaniya KNR v XXI veke [Strategic Milestones in the Development of China's Educational System in the XXI Century]. Problemy Dalnego Vostoka [Far Eastern Affairs], 2019, no. 4, pp. 145-153. DOI: $10.31857 / \mathrm{S} 013128120006104-5$.

6. Guruleva T.L. Tekhnologii sotsiokulturnoy integratsii inostrannykh studentov: opyt rossiyskokitayskogo sotrudnichestva [Technologies of SocioCultural Integration of Foreign Students: The Experience of Russian-Chinese Cooperation]. Vysshee obrazovanie v Rossii [Higher Education in Russia], 2016, no. 10, pp. 148-153.

7. Guruleva T.L., Bedareva N.I. Sotrudnichestvo Rossii i Kitaya v oblasti sozdaniya setevykh universitetov i sovmestnykh obrazovatelnykh uchrezhdeniy [Cooperation Between Russia and China in the Creation of Network Universities and Joint Educational Institutions]. Vysshee obrazovanie $v$ Rossii [Higher Education in Russia], 2019, no 4, pp. 108-123. DOI: https://doi.org/10.31992/0869-3617-2019-28-4-108-123.

8. Donetskaya S.S., Tszi Ts. Reformirovanie sistemy vysshego obrazovaniya $v$ Kitae: sovremennye itogi [Contemporary Results of the Reforming of Higher Education in China]. Vysshee obrazovanie v Rossii [Higher Education in Russia], 2018, vol. 27, no 12, pp. 79-92. DOI: https://doi.org/10.31992/0869-36172018-27-12-79-92.

9. Krasnova A.A. Razvitie sistemy nepreryvnogo obrazovaniya $v$ Kitae [The Development of Continuing Education in China]. Vestnik Rossiyskogo universiteta druzhby narodov. Seriya: Informatizatsiya obrazovaniya [RUDN Journal of Informatization in Education], 2015, no. 3, pp. 96-105.

10. Krasnova G.A. Setevoe vzaimodeystvie vuzov: sravnitelnyy analiz podkhodov $\mathrm{k}$ realizatsii sovmestnykh obrazovatelnykh programm $v$ Kitae i Rossii [Network Interaction of Universities: A Comparative Analysis of Approaches to the Implementation of Joint Educational Programs in China and Russia]. Vestnik Rossiyskogo universiteta druzhby narodov. Seriya: Informatizatsiya obrazovaniya [RUDN Journal of Informatization in Education], 2016, no. 3, pp. 123-130.

11. Krasnoshchekov V.V. Obespechenie kachestva rossiysko-kitayskikh programm vysshego obrazovaniya [Quality Assurance of Russian-Chinese Higher Education Programs]. Sovremennye problemy nauki i obrazovaniya [Modern Problems of Science and Education], 2019, no. 3. URL: http://www.scienceeducation.ru/ru/article/view?id=28853 (accessed 18 January 2020).

12. Li Ya. Novaya dinamika vysshego obrazovaniya v Kitae [New Dynamics of Higher Education in China]. Vestnik Novosibirskogo gosudarstvennogo pedagogicheskogo universiteta [Novosibirsk State Pedagogical University Bulletin], 2015, no. 6 (28), pp. 151-160.

13. Siun L. Vysshee obrazovanie kak instrument «myagkoy sily» Rossii i Kitaya: avtoref. dis. ... kand. polit. nauk [Higher Education as an Instrument of the "Soft Power" of Russia and China. Cand. polit. sci. abs. diss.]. Moscow, 2018. 33 p.

14. Tereshchenko T.M., Pravdikova A.V. Opyt vnedreniya i realizatsii sovmestnykh rossiysko-kitayskikh obrazovatelnykh programm [Implementation and Realization of Joint Russian-Chinese Educational Programs]. Pedagogicheskoe obrazovanie v Rossii [Pedagogical Education in Russia], 2016, no. 10, pp. 38-42.

15. Filimonova N.Yu., Romanyuk E.S. Kitayskie studenty v vuzakh Rossii [Chinese Students in Russian Universities]. Vysshee obrazovanie v Rossii [Higher Education in Russia], 2014, no. 8-9, pp. 76-81.

16. Filippov V.M., Sun Yu. Rol Universiteta Shankhayskoy organizatsii sotrudnichestva $\mathrm{V}$ sopryazhenii obrazovatelnykh prostranstv Evrazii [The Role of the University of Shanghai Cooperation Organization in Conjunction of the Educational Spaces of Eurasia]. Gosudarstvennaya sluzhba [Public Administration], 2015, no. 6 (98). URL: https://pajournal.igsu.ru/articles/r102/3560/ (accessed 26 January 2020).

17. 2016 nian quanguo jiaoyu shiye fazhan tongji gongbao [National Statistical Report on Education Development for 2016]. URL: http://www.moe.gov.cn/ jyb_sjzl/sjzl_fztjgb/201707/t20170710_309042.html (accessed 26 January 2020). (in Chinese).

18. 2017 nian quanguo jiaoyu shiye fazhan tongji gongbao [National Statistical Report on Education Development for 2017]. URL: http://www.moe.gov.cn/ jyb_sjzl/sjzl_fztjgb/201807/t20180719_343508.html (accessed 26 January 2020). (in Chinese). 
19. 2018 nian quanguo jiaoyu shiye fazhan tongji gongbao [National Statistical Report on Education Development for 2018]. URL: http://www.moe.gov.cn/ jyb_sjzl/sjzl_fztjgb/201907/t20190724_392041.html (accessed 26 January 2020). (in Chinese).

20. 2019 nian quanguo gaodeng xuexiao mingdan [List of National Higher Education Institutions of China in 2019]. URL: http://www.moe.gov.cn/ jyb_xxgk/s5743/s5744/201906/t20190617 386200.html (accessed 26 January 2020). (in Chinese).

21. Zhonggong zhongyang, guowuyuan yinfa "Zhongguo jiaoyu xiandaihua 2035" [The Central Committee of the Communist Party of China and the State Council Issued the Document "China Education Modernization 2035"]. URL: http:/www.gov.cn/ zhengce/2019-02/23/content_5367987.htm (accessed 26 January 2020). (in Chinese).

22. Zhonghua renmin gongheguo yiwu jiaoyu fa [Compulsory Education Law of the People's Republic of China]. URL: http://www.npc.gov.cn/npc/c30834/ 201901/21b0be5b97e54c5088bff17903853a0d.shtml (accessed 26 January 2020). (in Chinese).

23. Zhonghua renmin gongheguo jiaoyu $f a$ [Education Law of the People's Republic of China]. URL: http://www.crs.jsj.edu.cn/index.php/default/news/ index/13 (accessed 26 January 2020). (in Chinese).

24. Xi Jinping. Zai zhongguo gongchandang di shi jiu ci quanguo daibiao dahui shang de baogao [Xi Jinping. Report at the $19^{\text {th }}$ National Congress of the Communist Party of China]. URL: http://cpc.people. com.cn/n1/2017/1028/c64094-29613660.html (accessed 26 January 2020). (in Chinese).
25. Shi ba jie wu zhongquanhui baogao quanwen [Report at the $5^{\text {th }}$ Plenum of the Central Committee of the Communist Party of China of the $18^{\text {th }}$ Convocation (Full Text)]. URL: http://www.yjbys.com/news/389856.html (accessed 17 July 2018). (in Chinese).

26. Guojia zhong chang qi jiaoyu gaige he fazhan guihua gangyao 2010-2020 nian [State Program of the National Medium and Long-term Education Reform and Development Plan for 2010-2020]. URL: http:// www.china.com.cn/policy/txt/2010-03/01/content_ 19492625.htm (accessed 15 July2018). (in Chinese).

27. Guomin jingji he shehui fazhan di shi san ge wu nian guihua gangyao [Program of the $13^{\text {th }}$ FiveYear Plan for National Economic and Social Development]. URL: http://kjtg. hljxm.gov.cn/index! contentall.action?document.id=106254 (accessed 26 January 2020). (in Chinese).

28. Jiaoyubu, caizhengbu, guojia fazhan gaigewei guanyu gongbu shijie yiliu daxue he yiliu xueke jianshe gaoxiao ji jianshe xueke mingdan tongzhi [Notice of the Ministry of Education, the Ministry of Finance, and the National Development and Reform Commission on Announcing the List of World-Class Universities and Disciplines]. URL: http://www.moe.gov.cn/srcsite/A22/ moe_843/201709/t20170921_314942.html (accessed 26 January 2020). (in Chinese).

29. Tongchou tuijin shijie yiliu daxue he yiliu xueke jianshe zongti fang'an [Overall Plan for the Construction of World-Class Universities and Disciplines]. URL: http://www.moe.gov.cn/jyb_xxgk/ moe_1777/moe_1778/201511/t20151105_217823.html (accessed 26 January 2020). (in Chinese).

\section{Information About the Author}

Tatiana L. Guruleva, Doctor of Sciences (Pedagogy), Associate Professor, Leading Researcher, Institute of Far Eastern Studies of the Russian Academy of Sciences, Prosp. Nakhimovskiy, 32, 117997 Moscow, Russian Federation; Professor, Department of Linguistics and Translation, Russian State Social University, Vilgelma Pika St., 4, Bld. 1, 129226 Moscow, Russian Federation, gurulevatatiana@mail.ru, https://orcid.org/0000-0003-0253-0075

\section{Информация об авторе}

Татьяна Леонидовна Гурулева, доктор педагогических наук, доцент, ведущий научный сотрудник, Институт Дальнего Востока РАН, просп. Нахимовский, 32, 117997 г. Москва, Российская Федерация; профессор кафедры лингвистики и перевода, Российский государственный социальный университет, ул. Вильгельма Пика, 4, стр. 1, 129226 г. Москва, Российская Федерация, gurulevatatiana@mail.ru, https://orcid.org/0000-0003-0253-0075 